\title{
Induction of atypical cell death in thyroid carcinoma cells by the indirubin derivative 7-bromoindirubin-3'-oxime (7BIO)
}

\author{
Martina Broecker-Preuss ${ }^{1,2^{*}}$, Nina Becher-Boveleth ${ }^{1,3}$, Susanne Gall ${ }^{1}$, Katrin Rehmann ${ }^{1,2}$, Susann Schenke \\ and Klaus Mann 1,4
}

\begin{abstract}
Background: The indirubin derivative 7-bromoindirubin-3'-oxime (7BIO) has already shown anticancer properties by causing cell death in some tumour cell lines and may be a new therapeutic option for treatment-resistant tumour cells. Since dedifferentiated and anaplastic thyroid carcinomas do not take up radioiodine and are insensitive to chemotherapeutic treatment and external radiation, direct cell death induction in these tumour cells may be a promising approach. We thus investigated the effect of $7 \mathrm{BIO}$ on thyroid carcinoma cell lines of different histological origins and characterized the type of cell death induction by $7 \mathrm{BIO}$.

Methods: Cell viability was measured with MTT assay. Cell death was analysed by caspase 3/7 activity, lactate dehydrogenase liberation, caspase cleavage products, DNA fragmentation, cell cycle phase distribution and LC3B analysis.

Results: After 7BIO treatment, cell viability was reduced in all 14 thyroid carcinoma cell lines investigated. Treated cells showed DNA fragmentation, cell cycle arrest and lactate dehydrogenase liberation but no LC3B cleavage. Caspase activation following 7BIO treatment was found in five of six cell lines investigated. Interestingly, inhibition of caspases had no effect on viability of the cells after $7 \mathrm{BIO}$ incubation.

Conclusions: Our results indicate that $7 \mathrm{BIO}$ efficiently killed dedifferentiated thyroid carcinoma cells. It induced a non-classical kind of cell death that was caspase-independent and includes DNA fragmentation. 7BIO and related indirubin components thus may have value as a new therapeutic option for dedifferentiated thyroid cancer irrespective of the exact target molecules and the kind of cell death they induce.
\end{abstract}

Keywords: Dedifferentiated thyroid carcinoma, Indirubins, 7BIO, Cell death

\section{Background}

The bis-indole alkaloid indirubin is the active compound of a traditional Chinese herbal medicine used for treatment of chronic myelocytic leukemia. Thus, indirubins are of interest as possible anti-tumour substances [1]. Indirubin and its analogues (referred to as indirubins) are naturally found in certain indigo-dye producing plants and sea shells [Review: 2], while various derivatives have been synthesized to improve the effects on

\footnotetext{
*Correspondence: martina.broecker@uni-due.de

2 Present Address: Department of Clinical Chemistry, University Hospital Essen, Hufelandstr. 55, Essen, Germany

Full list of author information is available at the end of the article
}

tumour cells. Among the bromo-substituted indirubins, 7-bromoindirubin-3'-oxime (7BIO) showed activity against some tumour cell lines by inducing cell death [3-5]. While other indirubins were shown to inhibit cyclin-dependent kinases (CDKs), glycogen synthase kinase-3 (GSK-3), Janus activated kinases (JAK), SRC and subsequently STAT3 and AKT [6-11], 7BIO showed only marginal inhibitory effects towards these kinases but triggered a rapid cell death [3]. An inhibitory screening of $7 \mathrm{BIO}$ on 85 kinases was performed that revealed that only FLT3 was inhibited by 7BIO with an IC50 below $1 \mu \mathrm{M}$ [3]. Despite the fact that the exact molecular mechanism of action of 7BIO is not yet known, it may be valuable for inducing cell death in tumour cells. 
The imbalance between cell division and cell death pathways is one characteristic feature of cancer cells and contributes to the "hallmark of cancer cells" [12]. Decreased cell death in general is associated with hyperproliferative diseases like cancer and resistance to cell death contributes to uncontrolled tumour proliferation [13]. Cell death can be induced by different pathways that are regulated by different intracellular signalling cascades, i.e., mainly apoptosis, necrosis, necroptosis, and autophagy [Review: 14]. According to the Nomenclature Committee on Cell Death [15], apoptosis is a form of regulated cell death characterized by the activation of caspases, a family of cysteine proteases [16]. Caspase activation leads to a degradation of specific substrates, to a fragmentation of nuclear DNA, and, in turn, to characteristic morphological changes of the affected cells [17, 18]. Necrosis on the other hand is characterized by cell swelling and early plasma membrane permeabilisation followed by cell rupture and the release of cellular material [Review: 19]. Biochemically, lysosomal hydroxylases are often released during necrosis and are involved in cell destruction [20]. Autophagy, as the third type of cell death mechanism, describes the process of self-digestion of cellular components by the cells [Review: 21]. During this regulated cellular process organelles and cell components are degraded and recycled and thus, in addition to inducing death in single cells, it is also a survival mechanism for the whole cell population in situations like starvation or cellular damage [22].

Thyroid carcinoma is the most common endocrine malignancy, accounting for nearly $95 \%$ of malignant endocrine tumours [23]. Most thyroid carcinomas (95$97 \%)$ originate from follicular thyroid cells, whereas about $3-5 \%$ of thyroid carcinomas are medullary subtypes derived from C-cells [24]. About $90 \%$ of the thyroid cancers of follicular cell origin are well differentiated papillary thyroid carcinoma (PTC; 70-80\%) or follicular thyroid carcinoma (FTC; $10-20 \%)$. While differentiated subtypes still take up radioiodine and have a good prognosis, initially $10 \%$ or less of thyroid carcinomas are poorly differentiated or undifferentiated, anaplastic subtypes [24, 25]. Loss of differentiation includes loss of radioiodine uptake and storage and an aggressive and infiltrative growth pattern. Thus, dedifferentiated and anaplastic thyroid carcinomas (ATC) are tumours that are insensitive to radioiodine treatment, chemotherapeutic treatment, and external radiation and have a bad prognosis $[26,27]$. A subgroup of patients with differentiated PTC or FTC also get recurrent disease even under TSH suppressive therapy, even though most PTC and FTC patients are successfully treated with surgery and subsequent radioiodine treatment to destroy residual tumour cells [23, 26]. Patients with recurrent disease have different outcomes due to the degree of dedifferentiation of their tumour and due to its ability to take up radioiodine $[26,28]$. Chemotherapeutic treatment of dedifferentiated or anaplastic thyroid carcinoma is less effective with partial response rates of $25 \%$ or less [29, 30]. Since most cytotoxic drugs kill cells by inducing cell death pathways [14], the resistance of thyroid carcinoma cells towards these drugs may point to the cells' reduced ability to undergo cell death. Thus, for dedifferentiated and anaplastic thyroid cancer, facilitating cell death induction is one new therapeutic option. Since 7BIO had already shown anti-tumour activities in other cell models, we performed this study to evaluate the effectiveness of 7BIO in thyroid carcinoma cells.

\section{Methods}

\section{Compounds and antibodies}

$7 \mathrm{BIO}$ came from Enzo Life Sciences (Farmingdale, NY, USA), 3-methyladenine (3-MA) and $N$-(2-Quinolyl)valylaspartyl-(2,6-difluorophenoxy)methyl ketone (Q-VD$\mathrm{OPh}$ ) were provided by Millipore/Calbiochem (MA, USA), obatoclax and staurosporine were from Selleck Chemicals (Houston, TX, USA). All compounds were dissolved in DMSO to 5-10 mM, stored in aliquots at $-20{ }^{\circ} \mathrm{C}$ and further diluted in the appropriate medium. Microtubule-associated protein 1A/1B-light chain B (LC3B) antibodies were from Cell Signaling Technology (Danvers, MA, USA).

\section{Cell lines and cell culture}

Cell lines from different subtypes of thyroid cancer were used in this study: SW1736 [31], HTh7 [32], C643 [33], HTh74 [34], 8305C [35] and 8505C [36] were derived from ATC. BHT101 [37], B-CPAP [38] and TPC1 [39] were from PTC. ML1 [40], TT2609 [41], FTC133 [42], FTC236 [42] and FTC238 [42] were derived from FTCs. The FTC133, FTC236 and FTC238 cell lines [42] were derived from a single primary FTC, a lymph node metastasis and a lung metastasis from the same patient. Jurkat leukemia cells and HepG2 hepatocellular carcinoma cells were used as controls. SW1736, HTh7, HTh74 and C643 cells were kindly provided by Prof. Heldin (Uppsala, Sweden), the other cell lines were purchased from ATCC (Manassas, Virginia, USA), ECACC (Salisbury, UK) and DSMZ (Braunschweig, Germany).All cells were grown in their appropriate medium supplemented with $10 \%$ foetal bovine serum (FBS; Life Technologies, Paisley, PA) at $37^{\circ} \mathrm{C}$ at $5 \% \mathrm{CO}_{2}$.

\section{Cell proliferation studies}

For the proliferation assays, $1 \times 10^{4}-5 \times 10^{4}$ cells (depending on the cell line) were seeded in each well of a 96 well plate. After $24 \mathrm{~h}$, medium was removed and 
culture medium without FBS containing $0.1 \%$ bovine serum albumin (BSA) and the concentrations of 7BIO, Q-VD-OPh, 3-MA or a combination of 7BIO and Q-VD$\mathrm{OPh}$ or 3-MA as indicated or vehicle was added. After $48 \mathrm{~h}$, viable cells were stained with the Cell Titer Aqueous One Solution assay for 2-3 h (Promega, Madison, WI, USA) and optical density at $490 \mathrm{~nm}$ was read using an Emax microplate photometer (Molecular Devices, Sunnyvale, CA, USA). Control values without stimulation were performed as 22 fold determinations, while all concentrations of 7BIO, Q-VD-OPh and 3-MA were tested in eightfold. The results and two-tailed Student's $\mathrm{t}$ tests were calculated with SoftMax pro software (Molecular Devices). The IC50 values (drug concentration that caused a $50 \%$ reduction in MTT assay) were calculated with four parameter logistic function dose-response curves using Sigma Plot software (Systat, San Jose, CA, USA).

\section{Determination of $\mathrm{LDH}$ release and caspase $3 / 7$ activity measurement}

The CytoTox-ONE homogeneous membrane integrity assay (Promega) was used to measure the release of lactate dehydrogenase (LDH) from damaged cells. Activity of caspases 3 and 7 was measured by the Apo-ONE homogeneous Caspase-3/7 assay (Promega). For both assays, cells were seeded and grown as described above, except that black 96 clear bottom well plates were used. On day 2, medium was removed and $100 \mu \mathrm{l}$ culture medium with $0.1 \%$ BSA containing $3 \mu \mathrm{M} 7 \mathrm{BIO}$ was added to each well. After $24 \mathrm{~h}, 50 \mu \mathrm{l}$ of medium from each well was transferred to a second 96 well plate and equilibrated to $20^{\circ} \mathrm{C} .50 \mu \mathrm{l}$ of CytoTox reagent was added and the solution was incubated for $10 \mathrm{~min}$ in the dark at room temperature. After adding $25 \mu \mathrm{l}$ of stop solution, fluorescence was determined with an excitation wavelength of $560 \mathrm{~nm}$ and an emission wavelength of $590 \mathrm{~nm}$. In each experiment, controls without cells and fully lysed cells as maximum LDH release controls were included. Caspase 3 and 7 activity in 7BIO-treated cells was determined in the original stimulation plate by adding of $50 \mu \mathrm{l}$ of Apo-ONE reagent that contained a fluorometric caspase substrate, cell lysis reagent and buffer. For positive controls, Jurkat cells that grow in suspension culture were harvested by centrifugation, resuspended in medium with $0.1 \% \mathrm{BSA}$, seeded and staurosporine or a combination of staurosporine and Q-VD-OPh was added. After $24 \mathrm{~h}, 96$ well plate was centrifuged, $50 \mu \mathrm{l}$ of supernatant was discarded and Apo-ONE assay was performed. After $60 \mathrm{~min}$, fluorescence was measured at $521 \mathrm{~nm}$ (emission) after excitation with $499 \mathrm{~nm}$. All values were determined as eightfold determinations. Calculation of results and two-tailed Student's $t$ tests were performed using SoftMax pro software (Molecular Devices).

\section{Cell cycle analysis}

To perform cell cycle analyses, cells were plated in 6 well plates $\left(1 \times 10^{5}-5 \times 10^{5}\right.$ cells per well $)$ in their appropriate growth medium. After $24 \mathrm{~h}$, medium was removed and medium without FBS containing $0.1 \%$ BSA and $3 \mu \mathrm{M} 7 \mathrm{BIO}$ was added for the indicated times. Cells were harvested and fixed in ice cold $70 \%$ ethanol. RNase A $(60 \mu \mathrm{g} / \mathrm{ml})$ and propidium iodide $(25 \mu \mathrm{g} / \mathrm{ml})$ in PBS were added and samples were incubated for $20 \mathrm{~min}$ at room temperature in the dark. The cellular DNA content was measured by means of a FACS Calibur flow cytometer (Becton-Dickinson, San Jose, CA) and the cell cycle stages and subG1 peak were analysed by ModFit Software (Verity Software House, Topsham, ME, USA).

\section{Cell stimulation and protein extraction}

For the ELISA and western blot analyses, cells were seeded on cell culture dishes $(15 \mathrm{~cm}$ diameter) and grown for 1-2 days until they reached $80-85 \%$ confluence. Full medium was replaced with medium containing $0.1 \%$ BSA and cells were maintained in this medium for $1 \mathrm{~h}$ before $3 \mu \mathrm{M} 7 \mathrm{BIO}$ or vehicle was added. Non-adherent Jurkat cells were harvested by centrifugation, resuspended in medium with $0.1 \% \mathrm{BSA}$ and staurosporine or a combination of staurosporine and Q-VD-OPh was added, respectively. After the indicated stimulation times, the medium was removed and the cells were washed with ice-cold PBS. All additional steps were performed on ice. For the cell lysis, a lysis buffer containing protease and phosphatase inhibitors (Complete protease inhibitor and phosStop phosphatase inhibitor, Roche Applied Science, Mannheim, Germany) was used. The lysates were clarified by centrifugation at $10,000 \times g$ for $10 \mathrm{~min}$ at $4{ }^{\circ} \mathrm{C}$. The protein concentration was determined with a modified Bradford assay (Bio-Rad Laboratories, Hercules, CA, USA).

\section{Cleaved caspase and cleaved PARP ELISA}

A semi-quantitative determination of cleaved caspase 3 (Asp175) and cleaved poly (ADP ribose) polymerase (PARP) as a marker of apoptosis induction and protease activation was performed by using specific sandwich ELISAs for these cleaved proteins (Cell Signaling Technologies). In brief, cells were plated, stimulated, and lysed as described above. $100 \mu \mathrm{l}$ of diluted cell lysate containing $100 \mu \mathrm{g}$ of total cell protein was incubated in each of the antibody coated well of the plate overnight at $4{ }^{\circ} \mathrm{C}$. After washing, we used an antibody specific for the cleaved protein and a HRP-labelled secondary antibody 
for detection. The TMB substrate reaction was stopped after $30 \mathrm{~min}$ at room temperature and the absorbance was measured at $450 \mathrm{~nm}$ (EMax microplate reader). The results were calculated as percent of unstimulated controls using SoftMax pro software (Molecular Devices).

\section{Western blot analyses}

Western blot analyses were performed to analyse the effects of $7 \mathrm{BIO}$ on LC3B cleavage. $30 \mu \mathrm{g}$ of total protein from vehicle stimulated and stimulated cells (see above) were denatured by boiling for $5 \mathrm{~min}$ in SDS sample buffer. Proteins were separated by SDS-PAGE on stain-free polyacryl-amide gels (Bio-Rad Laboratories) to enable loading control. After electrophoresis, optical densities of stained proteins in each lane were documented with a CCD camera system and verified using the Quantity One software (both Bio-Rad Laboratories). When the integrated optical densities of proteins in each lane did not differ more than $10 \%$, proteins were transferred to a nitrocellulose membrane (Bio-Rad Laboratories). After blocking with BSA, the blots were incubated with the LC3B primary antibody (Cell Signaling Technologies) in TBS containing $0.1 \%$ Triton X100 overnight at $4{ }^{\circ} \mathrm{C}$. After washing, an appropriate secondary antibody coupled to horseradish peroxidase was added. Detection of bound antigens was performed by an enhanced chemiluminescence detection kit (Amersham ECL Advance, GE Healthcare, Piscataway, NJ, USA). Signal intensity was evaluated with a CCD-camera (Bio-Rad Laboratories).

\section{Results}

Inhibition of proliferation after 7BIO treatment

14 thyroid cell lines derived from follicular, papillary and anaplastic thyroid carcinomas were treated with increasing concentrations of 7BIO or vehicle for $48 \mathrm{~h}$. For all cell lines, IC50 values measured by MTT assay are shown in Table 1. As examples, results for six cell lines are shown in Fig. 1; one data point represents the mean of eight values \pm standard deviation. We found IC50 values for 7BIO in a similar range for all cell lines examined independent of the subtype of thyroid carcinoma they were derived from (1.54-4.83 $\mu \mathrm{M})$. C643 anaplastic thyroid carcinoma cells had the lowest IC50 value $(1.54 \mu \mathrm{M})$ while BHT101 cells (dedifferentiated papillary thyroid carcinoma cell line) had the highest IC50 value for 7BIO (Table 1) with $4.83 \mu \mathrm{M}$, respectively. These results indicate that 7BIO is effective in reducing the number of viable thyroid carcinoma cells in cell lines derived from various thyroid carcinoma subtypes.

\section{Cell cycle analyses after $7 \mathrm{BIO}$ treatment}

Cell cycle analyses and the following experiments to determine the kind of cell death caused by $7 \mathrm{BIO}$ were
Table 1 IC50 values of thyroid carcinoma cell lines after $48 \mathrm{~h}$ of treatment with 7BIO (MTT assay)

\begin{tabular}{lll}
\hline Cell line & Origin & IC50 7BIO $(\boldsymbol{\mu M})$ \\
\hline FTC133 & Follicular & $1.98 \pm 0.32$ \\
FTC236 & Follicular & $2.21 \pm 0.30$ \\
FTC238 & Follicular & $2.17 \pm 0.27$ \\
ML1 & Follicular & $4.27 \pm 0.38$ \\
TT2609 & Follicular & $4.62 \pm 0.51$ \\
BHT101 & Papillary & $4.83 \pm 0.36$ \\
B-CPAP & Papillary & $4.73 \pm 0.40$ \\
TPC1 & Papillary & $4.68 \pm 0.37$ \\
SW1736 & Anaplastic & $2.52 \pm 0.18$ \\
HTh7 & Anaplastic & $3.08 \pm 0.25$ \\
C643 & Anaplastic & $1.54 \pm 0.21$ \\
HTh74 & Anaplastic & $2.06 \pm 0.18$ \\
$8305 C$ & Anaplastic & $3.30 \pm 0.27$ \\
$8505 C$ & Anaplastic & $4.32 \pm 0.41$ \\
\hline
\end{tabular}

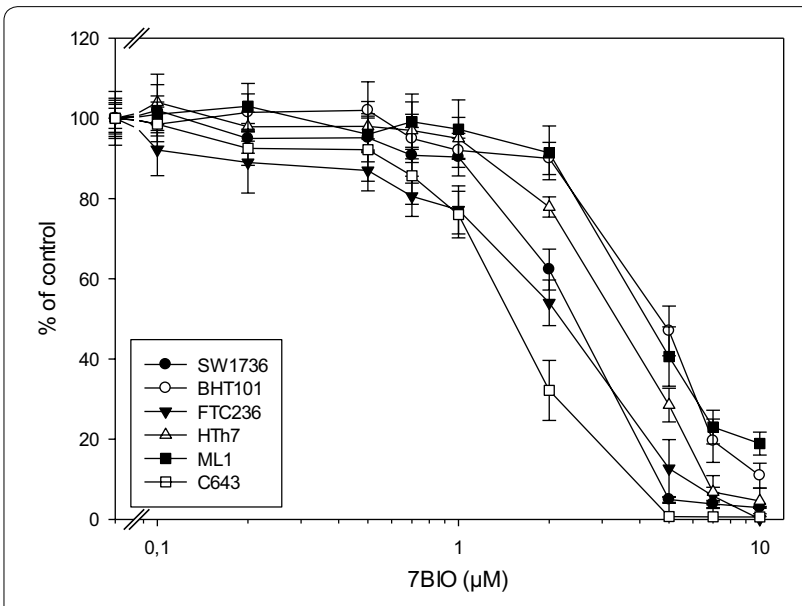

Fig. 1 Decreased viability of thyroid carcinoma cells after $7 \mathrm{BIO}$ incubation. Cells were cultured in the presence of increasing concentrations of $7 \mathrm{BIO}$ or vehicle control for $48 \mathrm{~h}$ and viability was assessed by MTT assay. Values represent percent of vehicle control, mean \pm standard deviation from eight-fold determinations. IC50 values are shown in Table 1

performed in the following six cell lines: FTC236 (FTC), ML1 (FTC), BHT101 (PTC), SW1736 (ATC), HTh7 (ATC), and C643 (ATC). Cell cycle analyses of the propidium iodide stained cellular DNA after a $24 \mathrm{~h}$ treatment with $3 \mu \mathrm{M} 7 \mathrm{BIO}$ showed a marked increase of cells in subG1 fraction in all cell lines analysed, pointing to cell death and DNA fragmentation induced by 7BIO treatment (Table 2; Fig. 2). Interestingly, the fraction of cells in subG1 fraction was the highest in the two follicular cell lines FTC236 and ML1 (43.6 and $44.0 \%$ of cells measured vs. 9.3-13.1\% in the other cell lines; Table 2). In the 
remaining living cells, the portion of cells in the G1 phase of the cell cycle was significantly increased after incubation with 7BIO in all cell lines except for C643 which exhibited a slight, but not significant decrease (Table 2). The portion of cells in the G2/M phase and/or the $\mathrm{S}$ phase of the cell cycle was diminished by 7BIO in all six cell lines investigated, although in different ways: while ML1 and BHT101 showed a decrease in both G2/M and S phases, SW1736 and HTh7 depicted only a decrease in $S$ phase. FTC238 had a reduction only in G2/M phase and $\mathrm{C} 643$ showed an increase of cells in the $S$ phase after $7 \mathrm{BIO}$ treatment, while the portion of cells in $\mathrm{G} 2 / \mathrm{M}$ phase was significantly diminished (Table 2).

\section{Cell death after 7BIO treatment}

Cells treated with 7BIO were analysed biochemically to evaluate the kind of cell death induced by this treatment. Figure 3 shows the LDH activity in supernatants of vehicle treated cells and cells incubated with $3 \mu \mathrm{M} 7 \mathrm{BIO}$ for $24 \mathrm{~h}$. All cell lines had a significantly elevated LDH content in the stimulation medium after $24 \mathrm{~h}$ of stimulation. LDH release in anaplastic SW1736, HTh7 and C643 cells was significantly higher than in follicular and papillary cell lines following 7BIO treatment. Elevated LDH activity in the cell culture medium pointed to a disruption of cell membranes with a release of LDH and other cytoplasmic components and thus reflected thyroid carcinoma cell disruption after the 7BIO treatment.

Caspase 3 and 7 measurements as well as the determination of the cleaved caspase and cleaved PARP were performed to investigate apoptotic cell death mechanisms after the 7BIO treatment in thyroid carcinoma cells. As shown in Fig. 4, caspase activities were significantly elevated after $24 \mathrm{~h}$ of $7 \mathrm{BIO}$ treatment in all thyroid carcinoma cell lines except C643. FTC236, ML1 and BHT101 cells showed a relatively small, but significant increase in caspase activity after 7BIO treatment, while SW1736 and HTh7 cells depicted a higher caspase activity after incubation with $7 \mathrm{BIO}$. Concentrations of cleaved caspase 3 and cleaved PARP as biochemical markers of activated caspases were also significantly elevated in all treated cells lines except C643 (Figs. 5, 6) pointing to an activation of the apoptosis machinery in these five cell lines caused by the treatment with 7BIO. However, the caspase activities depicted by our thyroid carcinoma cells were not as high as expected since with the concentration of $3 \mu \mathrm{M} 7 \mathrm{BIO}$, approximately half of the cells were dying (Fig. 1 and controlled by microscopy; data not shown). As positive controls for apoptosis induction, Jurkat cells were incubated with $2.5 \mu \mathrm{M}$ staurosporine. As already described in literature [43], this treatment caused apoptosis with caspase activation (952 $\pm 103 \%$ of untreated control), as well as an increase in cleaved caspase (1462 $\pm 98 \%$ of untreated control) and cleaved PARP $(1271 \pm 116 \%$ of untreated control). We performed co-incubation of thyroid carcinoma cell lines with 7BIO and the general caspase inhibitor Q-VD-OPh and measured viability after $48 \mathrm{~h}$. As shown in Table 3, co-incubation did not increase the viability of the cells indicating that the activation of caspases is not the determining step in cell death execution but plays a less important role in 7BIO induced cell death of the thyroid carcinoma cells examined in this study. As positive control for Q-VD-OPh treatment, co-incubation of Jurkat cells with staurosporine and Q-VD-OPh resulted in a decrease of apoptosis induction by staurosporine (caspase activity $135 \pm 19 \%$ of untreated control; cleaved

Table 2 Distribution of cell cycle phases in vehicle-treated and 7BIO-treated cells ( $24 \mathrm{~h}, 3 \boldsymbol{\mu M})$

\begin{tabular}{|c|c|c|c|c|c|c|}
\hline Cell line & Type & Status & \% subG1 & $\%$ G1 & $\%$ G2/M & $\% \mathrm{~S}$ \\
\hline \multirow[t]{2}{*}{ FTC236 } & Follicular & Untreated & $0.2 \pm 0.1$ & $38.4 \pm 4.3$ & $18.7 \pm 0.8$ & $42.9 \pm 3.0$ \\
\hline & & $7 B I O 24 \mathrm{~h}$ & $43.6 \pm 4.7^{*}$ & $48.7 \pm 4.0^{*}$ & $6.2 \pm 0.9^{*}$ & $45.1 \pm 5.1$ \\
\hline \multirow[t]{2}{*}{ ML1 } & Follicular & Untreated & $1.2 \pm 0.2$ & $39.4 \pm 5.0$ & $29.5 \pm 2.4$ & $31.1 \pm 3.5$ \\
\hline & & $7 \mathrm{BIO} 24 \mathrm{~h}$ & $44.0 \pm 5.3^{*}$ & $76.8 \pm 9.3^{*}$ & $16.9 \pm 1.5^{*}$ & $6.3 \pm 0.7^{*}$ \\
\hline \multirow[t]{2}{*}{ BHT101 } & Papillary & Untreated & $0.5 \pm 0.2$ & $51.3 \pm 4.3$ & $17.4 \pm 1.1$ & $31.4 \pm 1.5$ \\
\hline & & $7 \mathrm{BIO} 24 \mathrm{~h}$ & $11.5 \pm 2.1^{*}$ & $83.6 \pm 6.8^{*}$ & $10.4 \pm 0.7^{*}$ & $6.0 \pm 1.1^{*}$ \\
\hline \multirow[t]{2}{*}{ SW1736 } & Anaplastic & Untreated & $1.2 \pm 0.2$ & $36.4 \pm 3.7$ & $22.1 \pm 1.8$ & $41.5 \pm 2.4$ \\
\hline & & $7 \mathrm{BIO} 24 \mathrm{~h}$ & $12.7 \pm 1.6^{*}$ & $48.2 \pm 6.1^{*}$ & $18.5 \pm 3.4$ & $33.3 \pm 3.5^{*}$ \\
\hline \multirow[t]{2}{*}{ HTh7 } & Anaplastic & Untreated & $1.0 \pm 0.1$ & $52.0 \pm 6.4$ & $15.1 \pm 1.3$ & $32.9 \pm 2.8$ \\
\hline & & $7 \mathrm{BIO} 24 \mathrm{~h}$ & $13.1 \pm 1.5^{*}$ & $63.3 \pm 3.9^{*}$ & $17.3 \pm 1.5$ & $19.4 \pm 0.9^{*}$ \\
\hline \multirow[t]{2}{*}{ C643 } & Anaplastic & Untreated & $0.6 \pm 0.1$ & $53.8 \pm 6.7$ & $12.4 \pm 0.7$ & $33.7 \pm 1.2$ \\
\hline & & $7 \mathrm{BIO} 24 \mathrm{~h}$ & $9.3 \pm 1.1^{*}$ & $48.7 \pm 6.8$ & $5.5 \pm 0.3^{*}$ & $45.9 \pm 4.5^{*}$ \\
\hline
\end{tabular}

Values for G1-, G2/M- and S-phase are determined for the living cells that were not included in the sub-G1-peak

* Significant change ( $p<0.05$, Student's t test) compared to controls treated with vehicle 

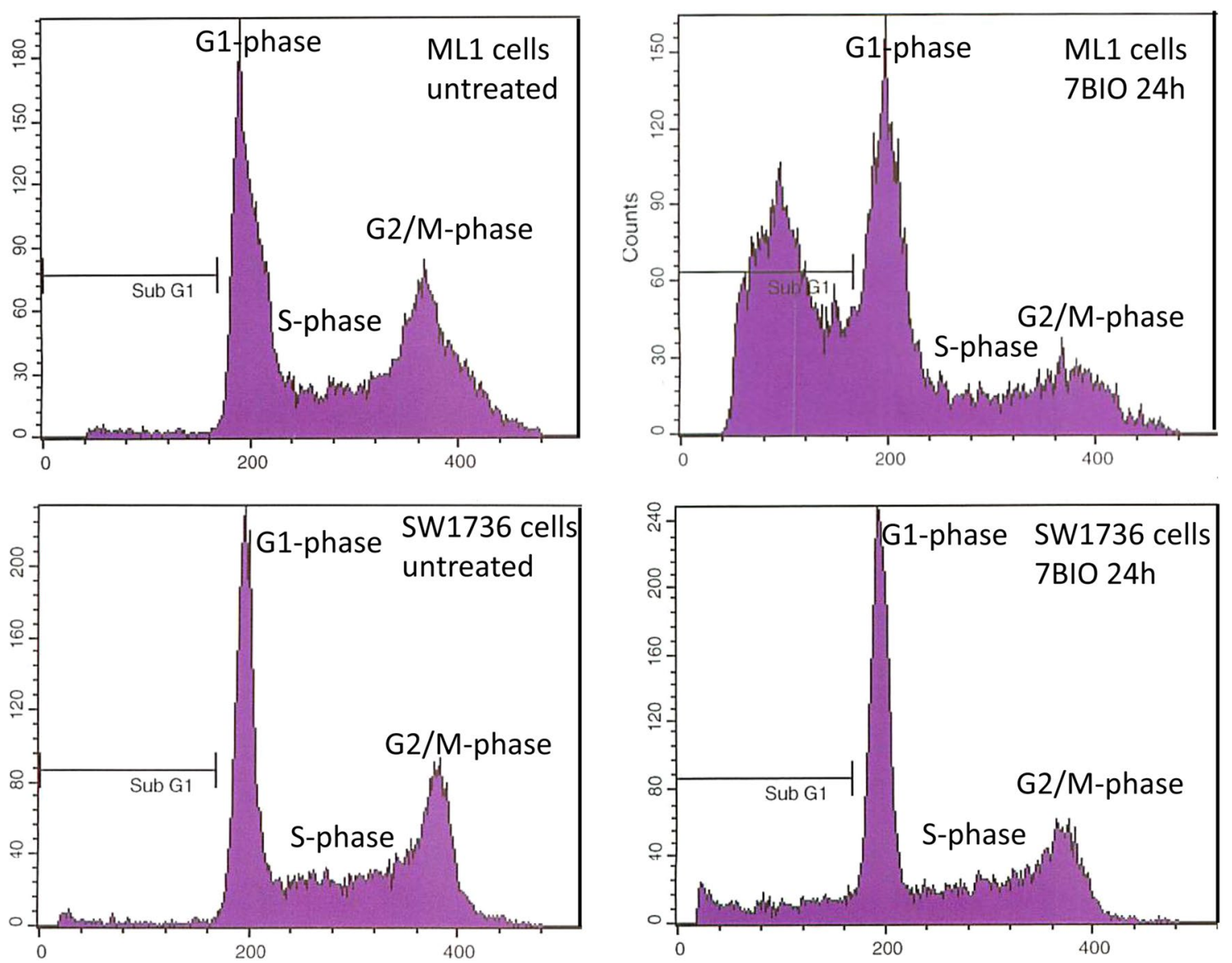

Fig. 2 Cell cycle changes in ML1 and SW1736 cells after incubation with $3 \mu \mathrm{M} 7 \mathrm{BIO}$ for $24 \mathrm{~h}$. Cell cycle analysis was conducted using FACS, results for ML1 and SW1736 cells are shown as examples. Besides the increase in subG1 peak, in the remaining living cells an increase in G1 phase and a decrease in $\mathbf{S}$ phase were observed. Values for all cell lines examined are shown in Table 2

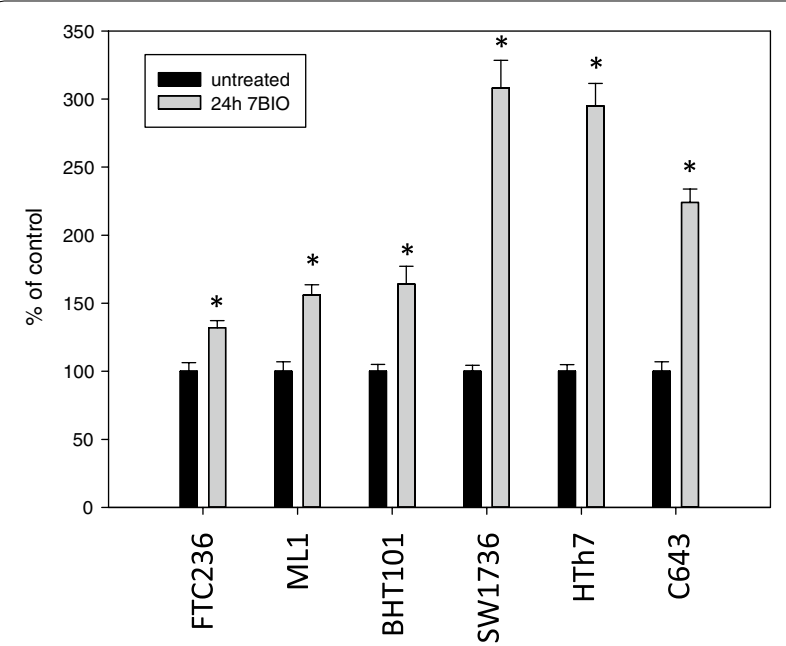

Fig. 3 Increased LDH-release into the cell culture medium after treatment with $3 \mu \mathrm{M} 7 \mathrm{BIO}$ for $24 \mathrm{~h}$. Values were determined by CytoTox-assay and are depicted as percent of vehicle-treated control, mean \pm standard deviation from eight-fold determinations; asterisk indicates significant increase $(p<0.05$, Student's t test)

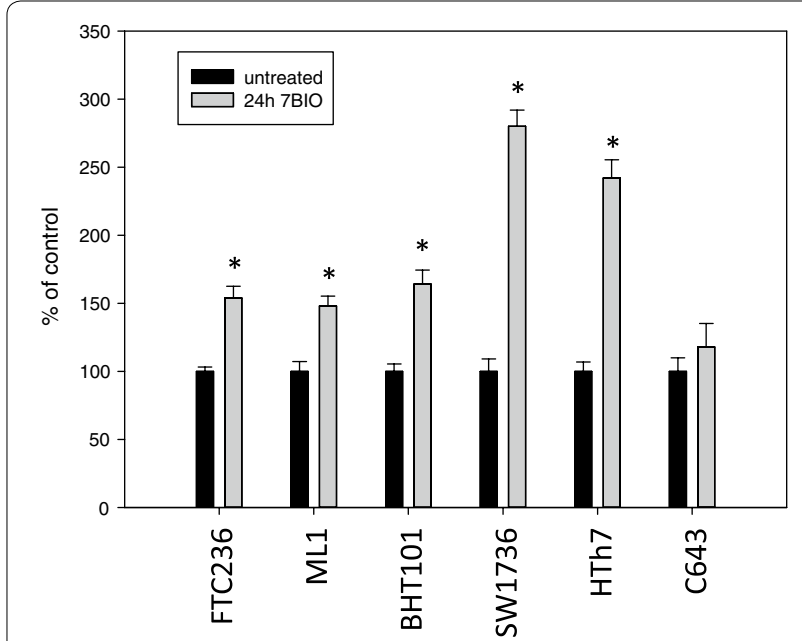

Fig. 4 Increased activity of caspase 3 and 7 in thyroid carcinoma cell lines treated with $3 \mu \mathrm{M} 7 \mathrm{BIO}$ for $24 \mathrm{~h}$. Values were determined by the ApoOne assay, mean \pm standard deviation from eight-fold determinations; asterisk indicates significant increase ( $p<0.05$, Student's $t$ test) compared to controls treated with vehicle 


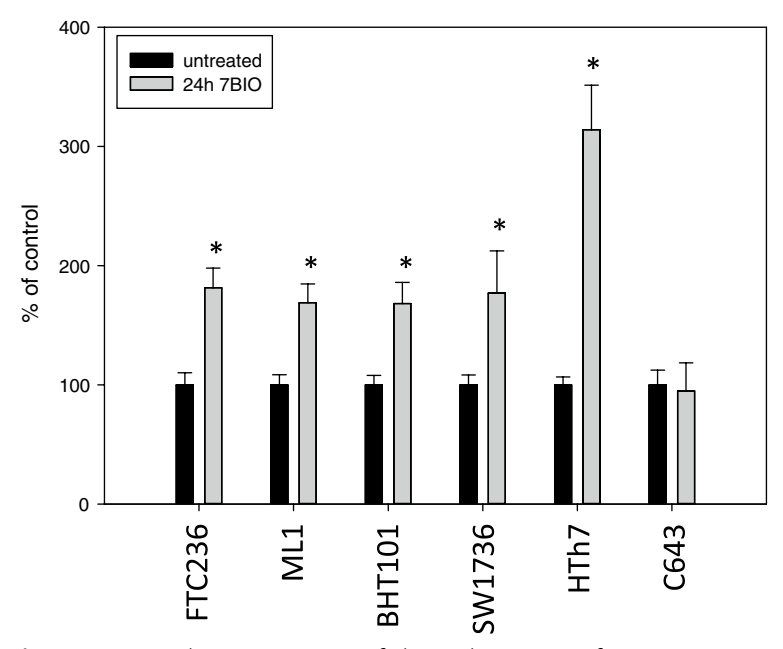

Fig. 5 Increased concentration of cleaved caspase 3 fragments in protein extracts of thyroid carcinoma cells treated with $3 \mu \mathrm{M} 7 \mathrm{BIO}$ for $24 \mathrm{~h}$. Results of an ELISA specific for caspase 3 fragments are depicted, mean \pm standard deviation from four-fold determinations; asterisk indicates significant increase ( $p<0.05$, Student's t test) compared to controls treated with vehicle

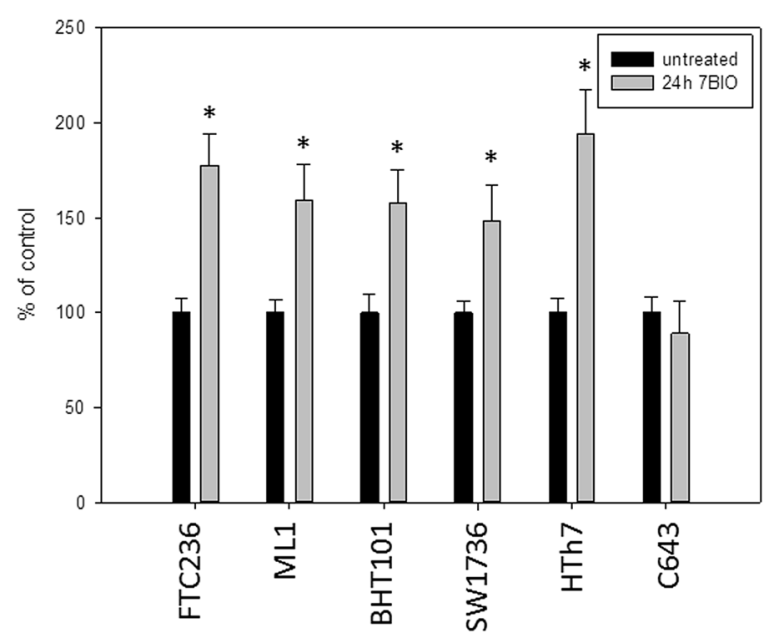

Fig. 6 Increased concentration of cleaved PARP fragments in protein extracts of thyroid carcinoma cells treated with $3 \mu \mathrm{M} 7 \mathrm{BIO}$ for $24 \mathrm{~h}$. Results of an ELISA specific for PARP fragments are depicted, mean \pm standard deviations from four-fold determinations; asterisk indicates significant increase ( $p<0.05$, Student's t test) compared to controls treated with vehicle

casapse $144 \pm 15 \%$ of untreated control; cleaved PARP $138 \pm 14 \%$ of untreated control).

Finally, LC3B conversion as a marker of autophagic cell death was examined by western blot analyses after $7 \mathrm{BIO}$ treatment. In all six thyroid carcinoma cells examined, $7 \mathrm{BIO}$ treatment did not result in LC3B cleavage which indicates that autophagic processes are not involved in cell death by 7BIO in thyroid carcinoma cells (Fig. 7). HepG2 cells treated with obatoclax, a BH3 mimetic that was already reported to cause autophagy and LC3B conversion [44] were used as positive control for these experiments and depicted a clear conversion of LC3B isoforms as expected (Fig. 7). Moreover, co-incubation with 7BIO and 3-MA, an autophagy-inhibitor, did not result in an increased viability of cells, which again speaks against an involvement of autophagic processes in 7BIO induced cell death (Table 3).

\section{Discussion}

In this study we showed the efficacy of the indirubin derivative $7 \mathrm{BIO}$ in inducing cell death in thyroid carcinoma cell lines. The kind of cell death induced was a nonclassical death with cell cycle block, DNA fragmentation as well as signs of non-classical apoptosis and necrosis.

The direct pharmacological induction of cell death is one possibility to overcome the resistance of cancer cells towards apoptosis that is a hallmark of tumour cells [12]. Dedifferentiated and anaplastic thyroid carcinoma cells that have lost the ability to take up radioiodine are tumour cells that are resistant to cell death induction by external radiation and chemotherapeutic treatment [23]. One reason for this resistance may be the inability of these cells to undergo apoptotic cell death [14]. Direct induction of cell death therefore presents one possibility of new treatment strategies for these tumours. $7 \mathrm{BIO}$ is an indirubin derivative that has been recently described as inducing cell death in some tumour cell lines of various origins [3-5]. In this study we showed that $7 \mathrm{BIO}$ is also active against dedifferentiated thyroid carcinoma cells.

$7 \mathrm{BIO}$ showed inhibitory effects on all 14 thyroid carcinoma cell lines investigated. IC50 values of our cell lines were in a narrow range $(1.54-4.83 \mu \mathrm{M})$ with the $\mathrm{C643}$ ATC cell line being the most sensitive cell line (IC50 of $1.54 \mu \mathrm{M}$; Table 1). All three papillary cell lines had IC50 values in the higher range (4.68-4.83 $\mu \mathrm{M}$; Table 1$)$ with BHT101 showing the highest IC50 value of our cell lines. In FTC and ATC cell lines, no correlation was found between the $7 \mathrm{BIO}$ sensitivity and the thyroid carcinoma subtype from which the cell lines had been derived (IC50 values in FTC cell lines 1.98-4.62 $\mu \mathrm{M}$; IC50 in ATC cell lines 1.54-4.32 $\mu \mathrm{M}$; Table 1$)$. The molecular reasons for these differences have to be elucidated and may be due to specific activation of signaling pathways in these histological thyroid carcinoma subtypes. Moreover, the IC50 values in thyroid carcinoma cells were in the lower range of that reported in $7 \mathrm{BIO}$-treated cell lines of other tumours (2.3-20.0 $\mu \mathrm{M}$ for breast cancer cell lines and approx. $12 \mu \mathrm{M}$ for SH-SY5Y neuroblastoma cells) $[3,5]$ After incubation with $10 \mu \mathrm{M} 7 \mathrm{BIO}$ for $48 \mathrm{~h}$, all cell lines except ML1 achieved values of less than $10 \%$ of control 
Table 3 Viability of cells after incubation with $3 \mu \mathrm{M}$ 7BIO, $5 \mu \mathrm{M}$ Q-VD-OPh, $2 \mu \mathrm{M}$ 3-MA or the combinations indicated for $24 \mathrm{~h}$ (MTT assay)

\begin{tabular}{|c|c|c|c|c|c|c|}
\hline Cell line & Origin & 7BIO & Q-VD-OPh & $7 B I O+Q-V D-O P h$ & 3-MA & $7 \mathrm{BIO}+3-\mathrm{MA}$ \\
\hline FTC236 & Follicular & $41.5 \pm 4.8^{*}$ & $102.4 \pm 6.9$ & $45.2 \pm 7.2$ & $94.6 \pm 10.4$ & $39.3 \pm 7.8$ \\
\hline ML1 & Follicular & $72.3 \pm 4.2^{*}$ & $105.1 \pm 6.0$ & $70.3 \pm 6.8$ & $106.0 \pm 7.5$ & $71.6 \pm 7.7$ \\
\hline BHT101 & Papillary & $68.3 \pm 8.3^{*}$ & $97.4 \pm 8.2$ & $71.2 \pm 5.3$ & $98.4 \pm 5.7$ & $69.4 \pm 9.4$ \\
\hline SW1736 & Anaplastic & $39.5 \pm 8.2^{*}$ & $95.7 \pm 11.4$ & $44.5 \pm 9.1$ & $104.6 \pm 9.7$ & $42.6 \pm 9.5$ \\
\hline HTh7 & Anaplastic & $50.8 \pm 6.2^{*}$ & $100.6 \pm 7.9$ & $53.5 \pm 8.3$ & $106.7 \pm 10.3$ & $49.2 \pm 7.5$ \\
\hline C643 & Anaplastic & $21.5 \pm 4.8^{*}$ & $104.5 \pm 9.7$ & $22.9 \pm 5.5$ & $99.1 \pm 6.9$ & $18.6 \pm 7.4$ \\
\hline
\end{tabular}

* Significant decrease ( $\mathrm{p}<0.05$, Student's t test) of 7BIO-treated cells compared to vehicle-treated controls, while treatment with Q-VD-OPh or 3-MA alone had no significant effect compared to vehicle-treated controls. Treatment with a combination of 7BIO and Q-VD-OPh or 7BIO and 3-MA was compared with the 7BIO treatment and had no significant effects

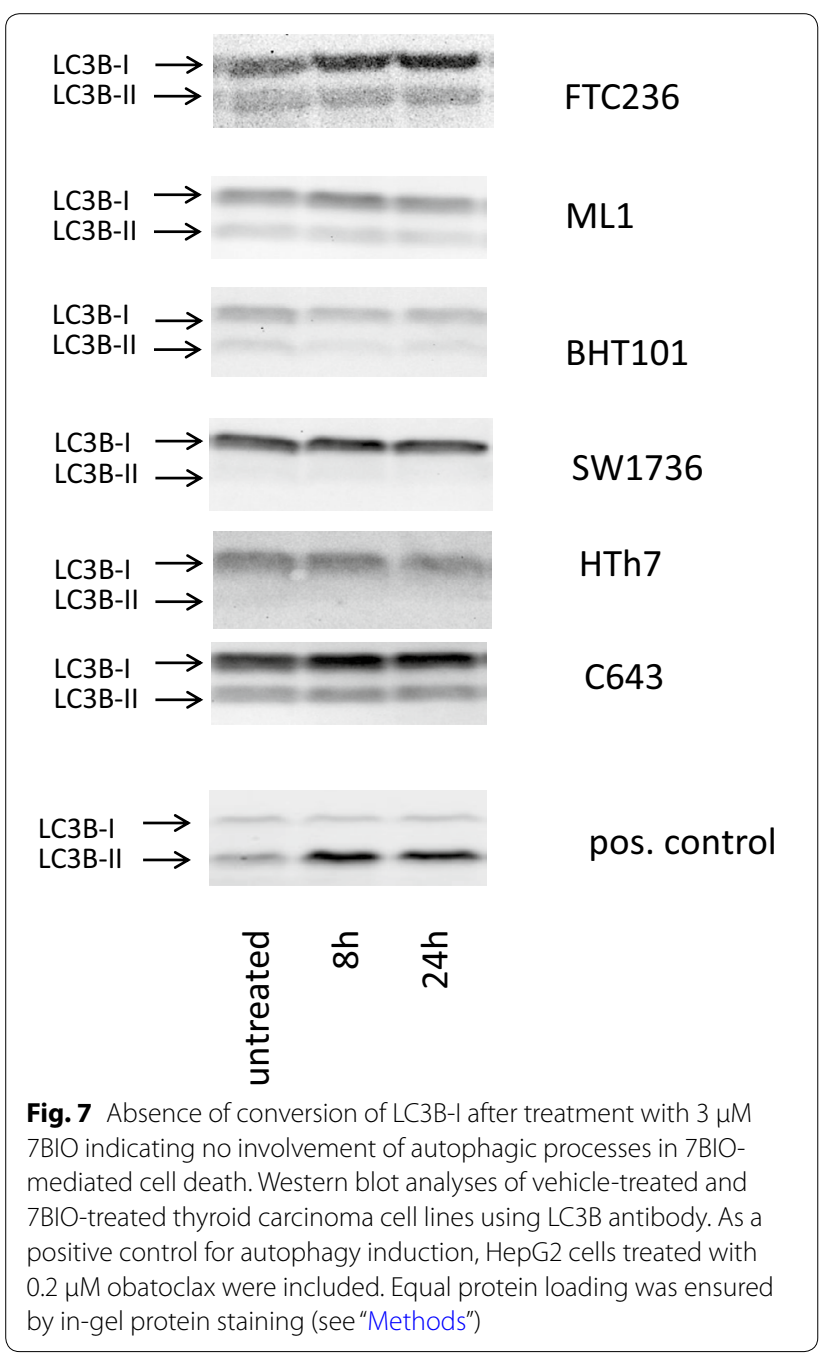

pointing to cell death in the majority of cells. A similar effect was already described by Ribas et al. [4] who showed that a $24 \mathrm{~h}$ treatment with $25 \mu \mathrm{M} 7 \mathrm{BIO}$ was lethal for the entire cell population of SH-SY5Y neuroblastoma cells and Jurkat leukaemia cells. Our biochemical data in six 7BIO-treated thyroid carcinoma cells argue for an atypical kind of cell death with biochemical signs of necrosis, DNA fragmentation, cell cycle inhibition, and atypical apoptosis. An increased LDH release typical for cell death by necrosis or secondary necrosis was seen in all six cell lines examined after 7BIO stimulation. In parallel, a small but significant increase in activity of caspases seen as direct caspase activity and increase in caspase cleavage products was found in all cells but C643. However, the significance of apoptosis-induction for cell death in 7BIO stimulated cells has to be questioned since the pan-caspase inhibitor Q-VD-OPh did not significantly prevent cell death by 7BIO (Table 3 ). Similar results have already been described in other cell lines for 7BIO. In neuroblastoma cells and the T cell leukemia cell line Jurkat, cell death by an apoptosis-independent manner was induced by $7 \mathrm{BIO}[3,4]$. In IMR- 5 , IMR-32, Jurkat and HL-60 cells, 7BIO treatment killed cells without activating caspases [3, 45]. Nicolaou et al. [5] on the other hand reported on 7BIO-mediated apoptosis induction by caspase-dependent as well as by caspase-independent pathways in breast cancer cell lines with an increase in the uncleaved caspases 3 and 9. From their own data and data in the literature these authors concluded that the response of different tumour cell lines to 7BIO through apoptotic or non-apoptotic mechanisms is a function of cell content [5]. Our own data suggest a cell death mechanism in which caspase activation occurs but is of little importance. This thesis is supported by the C643 anaplastic thyroid carcinoma cell line that was the most sensitive cell line towards 7BIO incubation but showed no significant activation of caspases by 7BIO. Caspase-independent cell death by apoptosis has already been described in various cell systems [46]. Physiologically it occurs in cells expressing endogenous caspase inhibitors like XIAP, CrmA or AIF [47-50]. In affected cells, apoptosis-like death is generally caused by serine-protease-mediated 
processes [51] that mediate the cleavage of cellular substrates similar to caspase-induction. The lysosomal proteases cathepsin D and B as well as calpains and other serine-proteases and are involved in this caspase-independent, apoptosis-like cell death [52-55]. The findings on the kind of cell death in our 7BIO-stimulated thyroid carcinoma cell lines are in accordance with these findings in cell lines undergoing cell death after various stimuli and also with the recently reported results of Ribas et al. [4] who reported on the involvement of serine proteases in 7BIO-induced cell death. Further experiments to analyse protease activation and to characterize intracellular targets of 7BIO may elucidate the exact kind of cell death induced by $7 \mathrm{BIO}$.

Regarding increases in subG1 fraction after 7BIO treatment, follicular FTC236 and ML1 cells interestingly showed a large fraction of cell in subG1 peak pointing to massive DNA fragmentation in these cells like already described by others [5]. In the other cell lines examined, fractions of cells in subG1 fraction were also significantly elevated, but to a lesser extent. Since DNA fragmentation can be mediated by various proteolytic enzymes, a caspase-independent mechanism of DNA fragmentation probably occurred with different degrees of activation in different 7BIO-treated thyroid carcinoma cell lines. In other cell lines, a caspase-independent, serine protease mediated DNA cleavage has already been described [51, $56,57]$. However, DNA fragmentation resulting in an elevated subG1 fraction may also occur during necrotic cell death [58] and in our cells may reflect a mixed kind of cell death with non-classical apoptosis and necrotic features. This interpretation is in accordance with data from the literature that cell death in vivo is often characterized not by a single cell death mode but can comprise elements of apoptotic, necrotic, and sometimes autophagic elements. Accordingly, various kinds of cell death can occur independently of each other or simultaneously resulting in a combined cell death phenotype [59, 60]. Cell cycle analyses of the remaining living cells pointed to different regulation mechanisms in various thyroid carcinoma cell lines treated with 7BIO. All cell lines except C643 showed a significant increase in the portion of cell in G1 fraction after incubation with 7BIO. This is in contrast to some other cell lines described in the literature that exhibited a decrease in G1 fraction following 7BIO treatment [3, $5]$ that is also described for other indirubins $[6,61,62]$. C643 cells showed a similar cell cycle distribution with a small, but not significant decrease in G1 phase (Table 2). The activation of different checkpoints of the cell cycle points to different cellular backgrounds of cells with respect to cell cycle regulatory proteins like $\mathrm{p} 53, \mathrm{pRb}$ as well as CDKs and its regulatory proteins [63]. Further studies may reveal the correlation of expression pattern of cell cycle regulatory proteins with the cellular effects of 7BIO treatment in different cells.

\section{Conclusion}

In summary, we found that 7BIO efficiently killed dedifferentiated and anaplastic thyroid carcinoma although its exact mechanism of action and the exact kind of cell death induced by $7 \mathrm{BIO}$ is not yet known and needs further investigation. Nevertheless, $7 \mathrm{BIO}$ and related indirubin components like $6 \mathrm{BIO}$ and other recently described indirubin derivatives [7-11] may have value as a new therapeutic option for dedifferentiated thyroid cancer.

\section{Abbreviations \\ 3-MA: 3-methyladenine; 7BIO: 7-bromoindirubin-3'-oxime; AIF: apoptosis- inducing factor; ATC: anaplastic thyroid carcinoma; CDK: cyclin-dependent kinase; CrmA: cytokine response modifier; FTC: follicular thyroid carcinoma; GSK-3: glycogen synthase kinase-3; JAK: Janus activated kinases; LDH: lactate dehydrogenase; PARP: poly-(ADP-ribose)-polymerase; PDTC: poorly diferentiated thyroid carcinoma; PTC: papillary thyroid carcinoma; Q-VD- OPh: N-(2-Quinolyl)valyl-aspartyl-(2,6-difluorophenoxy)methyl ketone; XIAP: $\mathrm{X}$-linked inhibitor of apoptosis protein.}

\section{Authors' contributions}

MBP drafted the project design, planned and conducted experiments, analysed the data and wrote the text. NBB planned and conducted experiments and discussed the data and text. SG, KR and SS conducted experiments and analysed data. KM contributed to project design, text writing and discussion of the data and text. All authors read and approved the final manuscript.

\section{Author details}

1 Division of Laboratory Research, Department of Endocrinology and Metabolism, University Hospital Essen, Hufelandstr. 55, Essen, Germany. ${ }^{2}$ Present Address: Department of Clinical Chemistry, University Hospital Essen, Hufelandstr. 55, Essen, Germany. ${ }^{3}$ Present Address: Clinic of Nuclear Medicine, University Hospital Essen, Hufelandstr. 55, Essen, Germany. ${ }^{4}$ Present Address: Center of Endocrinology Alter Hof München, Dienerstr. 12, Munich, Germany

\section{Acknowledgements}

The authors thank Ulrike Nichols for providing language help.

\section{Competing interests}

The authors declare that they have no competing interests.

Received: 30 July 2015 Accepted: 5 October 2015

Published online: 12 October 2015

\section{References}

1. Xiao Z, Hao Y, Liu B, Qian L. Indirubin and meisoindigo in the treatment of chronic myelogenous leukemia in China. Leuk Lymphoma. 2002:43:1763-8

2. Cooksey CJ. Tyrian purple: 6,6'-dibromoindigo and related compounds. Molecules. 2001;6:736-69.

3. Ribas J, Bettayeb K, Ferandin Y, Knockaert M, Garrofé-Ochoa X, Totzke F, Schächtele C, Mester J, Polychronopoulis P, Magiatis P, Skaltsounis A-L, Boix J, Meijer L. 7-Bromoindirubin-3'-oxime induces caspase-independent cell death. Oncogene. 2006;25:6304-18.

4. Ribas J, Yuste VJ, Garrofé-Ochoa X, Meijer L, Esquerda JE, Boix J. 7-Bromoindirubin-3'-oxime uncovers a serine protease-mediated paradigm of necrotic cell death. Biochem Pharmacol. 2008;76:39-52.

5. Nicolaou KA, Liapis V, Evdokiou A, Constantinou C, Magiatis P, Skaltsounis AL, Koumas L, Costeas PA, Constantinou Al. Induction of discrete 
apoptotic pathways by bromo-substituted indirubin derivatives in invasive breast cancer cell. Biochem Biophys Res Commun. 2012;425:76-82.

6. Hoessel R, Leclerc S, Endicott J, Noble M, Lawrie A, Tunnah P, Leost M, Damiens E, Marie D, Marko D, Niederberger E, Tang W, Eisenbrand $\mathrm{G}$, Meijer L. Indirubin, the active constituent of a chinese antileukaemia medicine, inhibits cyclin-dependent kinases. Nat Cell Biol. 1999:1:60-7.

7. Liu L, Nam S, Tian Y, Yang F, Wu J, Wang Y, Scuto A, Polychronopoulos P, Magiatis P, Skaltsounis L, Jove R. 6-Bromoindirubin-3'-oxime inhibits JAK STAT3 signaling and induces apoptosis of human melanoma cells. Cancer Res. 2011;71:3972-8.

8. Liu L, Gaboriaud N, Vougogianopoulou K, Tian Y, Wu J, Wen W, Skaltsounis L, Jove R. MLS-2384, a new 6-bromoindirubin derivative with dual JAK/ Src kinase inhibitory activity, suppresses growth of diverse cancer cells. Cancer Biol Ther. 2014;15:178-84.

9. Nam S, Wen W, Schroeder A, Herrmann A, Yu H, Cheng X, Merz K-H, Eisenbrand G, Li H, Yuan Y-C, Jove R. Dual inhibition of Janus and Src family kinases by novel indirubin derivative blocks constitutively-activated Stat3 signaling associated with apoptosis of human pancreatic cancer cells. Mol Oncol. 2013;7:369-78.

10. Liu L, Kritsanida M, Magiatis P, Gaboriaud N, Wang Y, Wu J, Buettner R, Yang F, Nam S, Skaltsounis L, Jove R. A novel 7-bromoindirubin with potent anticancer activity suppresses survival of human melanoma cells associated with inhibition of STAT3 and Akt signalling. Cancer Biol Ther. 2012;13:1255-61.

11. Nam S, Scuto A, Yang F, Chen WY, Park S, Yoo H-S, Konig H, Bhatia R, Cheng X, Merz K-H, Eisenbrand G, Jove R. Indirubin derivatives induce apoptosis of chrinoc myelogenous leujemia cells involving inhibition of Stat5 signaling. Mol Oncol. 2012;6:276-83.

12. Hanahan D, Weinberg RA. Hallmarks of cancer: the next generation. Cell. 2011;144:646-74.

13. Elmore S. Apoptosis: a review of programmed cell death. Toxicol Pathol. 2007:35:495-516.

14. Long JS, Ryan KM. New frontiers in promoting tumour cell death: targeting apoptosis, necroptosis and autophagy. Oncogene. 2012;31:5045-60.

15. Galluzzi L, Vitale I, Abrams JM, Alnemri ES, Baehrecke EH, Blagosklonny MV, Dawson TM, Dawson VL, El-Deiry WS, Fulda S, Gottlieb E, Green DR, Hengartner MO, Kepp O, Knight RA, Kumar S, Lipton SA, Lu X, Madeo F, Malorni W, Mehlen P, Nunez G, Peter ME, Piacentini M, Rubinsztein DC, Shi Y, Simon H-U, Vandenabeele P, White E, Yuan J, Zhivitivsky B, Melino G, Kroemer G. Molecular definitions of cell death subroutines: recommendations of the nomenclature committee on cell death 2012. Cell Death Differ. 2012;19:107-20.

16. Budihardjo I, Oliver H, Lutter M, Luo X, Wang X. Biochemical pathways of caspase activation during apoptosis. Annu Rev Cell Dev Biol. 1999;15:269-90.

17. Kerr JFR, Wyllie AH, Currie AR. Apoptosis: a basic biological phenomenon with wide-ranging implications in tissue kinetics. Br J Cancer. 1972;26:239-57.

18. Ferri KF, Kroemer G. Organelle-specific initiation of cell death pathways. Nat Cell Biol. 2001;3:E255-63.

19. Vandenabeele P, Galluzzi L, Vanden Berghe T, Kroemer G. Molecular mechanisms of necroptosis: an ordered cellular explosion. Nat Rev Mol Cell Biol. 2010;11:700-14.

20. Artal-Sanaz M, Samara C, Syntichaki P, Tavernarankis N. Lysosomal biogenesis and function is critical for necrotic cell death in Caenorhabditis elegans. J Cell Biol. 2006;173:231-9.

21. Choi AMK, Ryter SW, Levine B. Autophagy in human health and disease. New Engl J Med. 2013;368:651-62.

22. Levine B, Klionsky DJ. Development by self-digestion: molecular mechanisms and biological functions of autophagy. Dev Cell. 2004;6:463-77.

23. Kapiteijn E, Schneider TC, Morreau H, Gelderblom H, Nortier JWR, Smit JWA. New treatment modalities in advanced thyroid cancer. Ann Oncol. 2012;23:10-8

24. Kondo T, Ezzat S, Asa SL. Pathogenetic mechanisms in thyroid follicularcell neoplasia. Nat Rev Cancer. 2006;6:292-306.

25. Xing M. Molecular pathogenesis and mechanisms of thyroid cancer. Nat Rev Cancer. 2013:13:184-99.

26. Baudin E, Schlumberger M. New therapeutic approaches for metastatic thyroid carcinoma. Lancet Oncol. 2007;8:148-56.
27. Kebebew E, Greenspan FS, Clark OH, Woeber KA, McMillan A. Anaplastic thyroid carcinoma. Treatment, outcome and prognostic factors. Cancer. 2005;103:1330-5.

28. Schlumberger M, Sherman SI. Approach to the patient with advanced differentiated thyroid cancer. Eur J Endocrinol. 2012;166:5-11.

29. Sherman SI. Cytotoxic chemotherapy for differentiated thyroid carcinoma. Clin Oncol (R Coll Radiol). 2010;22:464-8.

30. Miccoli P, Materazzi G, Antonelli A, Panicucci E, Frustaci G, Berti P. New trends in the treatment of undifferentiated carcinomas of the thyroid. Langenbecks Arch Surg. 2007;392:397-404

31. Mark J, Ekedahl C, Dahlenfors R, Westermark B. Cytogenetical observations in five human anaplastic thyroid carcinomas. Hereditas. 1987; 107:163-74.

32. Carlson J, Nilsson K, Westermark B, Ponten J, Sundstöm C, Larsson E, Bergh J, Pahlman S, Busch C, Collins VP. Formation and growth of multicellular spheroids of human origin. Int J Cancer. 1983;31:523-33.

33. Heldin N-E, Gustavson B, Claesson-Welsh L, Hammacher A, Mark J, Heldin C-H, Westermark B. Aberrant expression of receptors for PDGF in an anaplastic thyroid carcinoma cell line. Proc Natl Acad Sci USA. 1988:85:9302-6.

34. Heldin NE, Cvejic D, Smeds S, Westermark B. Coexpression of functionally active receptors for thyrotropin and platelet-derived growth factor in human thyroid carcinoma cells. Endocrinology. 1991;129:2187-93.

35. Ito T, Seyama T, Mizuno T, Tsuyama N, Hayashi T, Hayashi Y, Dohi K, Nakamura N, Akiyama M. Unique association of p53 mutations with undifferentiated but not with differentiated carcinomas of the thyroid gland. Cancer Res. 1992;52:1369-71.

36. Ito T, Seyama T, Hayashi Y, Hayashi T, Dohi K, Mizuno T, Iwamoto K, Tsuyama N, Nakamura N, Akiyama M. Establishment of 2 human thyroidcarcinoma cell-lines (8305c, 8505c) bearing p53 gene-mutations. Int J Oncol. 1994;4:583-6.

37. Pályi I, Péter I, Daubner D, Vincze B, Lórincz I. Establishment, characterization and drug sensitivity of a new anaplastic thyroid carcinoma cell line (BHT-101). Virchows Archiv B Cell Pathol. 1993;63:263-9.

38. Fabien N, Fusco A, Santoro M, Barbier Y, Dubois PM, Paulin C. Description of a human papillary thyroid carcinoma cell line. Morphologic study and expression of tumoral markers. Cancer. 1994;73:2206-12.

39. Tanaka J, Ogura T, Sato H, Hatano M. Establishment and biological characterization of an in vitro human cytomegalovirus latency model. Virology. 1987;161:62-72.

40. Schönberger J, Bauer J, Spruß T, Weber G, Chahoud I, Eilles C, Grimm D. Establishment and characterization of the follicular thyroid carcinoma cell line ML-1. J Mol Med. 2000;78:102-10.

41. Geldorf AA, Versteegh LRT, van Mourik JC, Rooimans MA, Arwert F, Hermsen MA, Schadee-Eestermans IL, van Dongen GA, van der Valk P, van der Clement EHP, Lips P, Teule GJ. Clonally related but phenotypically divergent human cancer cell lines derived from a single follicular thyroid cancer recurrence (TT2609). Thyroid. 2001;11:909-17.

42. Goretzki PE, Frilling A, Simon D, Rastegar M, Ohmann C. Growth regulation of human thyrocytes by thyrotropin, cyclic adenosine monophosphate, epidermal growth factor and insulin-like growth factor. Front Horm Res Basel Karger. 1989;18:56-80.

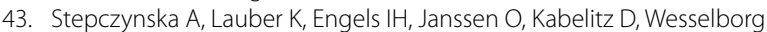
S, Schulze-Osthoff K. Staurosporine and conventional anticancer drugs induce overlapping, yet distinct pathways of apoptosis and caspase activation. Oncogene. 2001;20:1193-202.

44. Su JC, Tseng PH, Hsu CY, Tai WT, Huang JW, Ko CH, Lin MW, Liu CY, Chen KF, Shiau CW. RFX-dependent activation of SHP-1 induces autophagy by a novel obatoclax derivative in hepatocellular carcinoma cells. Oncotarget. 2014;5:4909-19.

45. Ferandin $Y$, Bettayeb K, Kritsanida M, Lozach O, Polychronopoulos P, Magiatis P, Skaltsounis AL, Meijer L. 3'-Substituted 7-halogenoindirubins, a new class of cell death inducing agents. J Med Chem. 2006;49:4638-49.

46. Tait SWG, Green DR. Caspase-independent cell death: leaving the set without the final cut. Oncogene. 2008;27:6452-61.

47. Okuno S, Shimizu S, Ito T, Nomura M, Hamada E, Tsujimoto Y, Matsuda $\mathrm{H}$. Bcl-2 prevents caspase-independent cell death. J Biol Chem. 1998:273:34272-7.

48. Denmeade SR, Lin XS, Tombal B, Isaacs JT. Inhibition of caspase activity does not prevent the signalling phase of apoptosis in prostate cancer cells. Prostate. 1999:39:269-79. 
49. Wilkinson JC, Cepero E, Boise LH, Duckett CS. Upstream regulatory role for XIAP in receptor-mediated apoptosis. Mol Cell Biol. 2004;24:7003-14.

50. Hagen E, Blomgren K, Bénit P, Kroemer G, Modjtahedi N. Life with or without AIF. Trends Biochem Sci. 2010;35:278-87.

51. Egger L, Schneider J, Rheme C, Tapernoux M, Häcki J, Borner C. Serine proteases mediate apoptosis-like cell death and phagocytosis under caspase-inhibiting conditions. Cell Death Differ. 2003;10:1188-203.

52. Deiss LP, Galinka H, Berissi H, Cohen O, Kimchi A. Cathepsin D protease mediates programmed cell death induced by interferon-gamma, Fas/ APO-1 and TNF-alpha. EMBO J. 1996;15:3861-70.

53. Guicciardi ME, Deussing J, Miyoshi H, Bronk SF, Svingen PA, Peters C, Kaufmann SH, Gores GJ. Cathepsin B contributes to TNF-alpha-mediated hepatocyte apoptosis by promoting mitochondrial release of cytochrome c. J Clin Invest. 2000;106:1127-37.

54. Johnson DE. Noncaspase proteases in apoptosis. Leukemia. 2000;14:1696-703.

55. Nakagawa T, Yuan J. Cross-talk between two cysteine protease families. Activation of caspase-12 by calpain in apoptosis. J Cell Biol. 2000;150:887-94.
56. Hughes FM, Evans-Storms RB, Cidlowski JA. Evidence that non-caspase proteases are required for chromatin degradation during apoptosis. Cell Death Differ. 1998;5:1017-27.

57. Kitazumi I, Tsukahara M. Regulation of DNA fragmentation: the role of caspases and phosphorylation. FEBS J. 2010;278:427-41.

58. Mattes MJ. Apoptosis assays with lymphoma cell lines: problems and pitfalls. Br J Cancer. 2007;96:928-36.

59. Samara C, Syntichaki P, Tavernarakis N. Autophagy is required for necrotic cell death in Caenorhabditis elegans. Cell Death Differ. 2008;15:105-12.

60. Bellot G, Garcia-Medina R, Gounon P, Chiche J, Roux D, Pouyssegur J, Mazure NM. Hypoxia-induced autophagy is mediated through hypoxiainducible factor induction of BNIP3 and BNIP3 $L$ via their BH3 domains. Mol Cell Biol. 2009;29:2570-81.

61. Damiens E, Baratte B, Marie D, Eisenbrand G, Meijer L. Anti-mitotic properties of indirubin-3'-monoxime, a CDK/GSK-3 inhibitor: induction of endoreplication following prophase arrest. Oncogene. 2001;20:3786-97.

62. Marko D, Schätzle S, Friedel A, Genzlinger A, Zankl H, Meijer L, Eisenbrand G. Inhibition of cyclin-dependent kinase 1 (CDK1) by indirubin derivatives in human tumour cells. Br J Cancer. 2001;84:283-9.

63. Johnson DG, Walker CL. Cyclins and cell cycle checkpoints. Annu Rev Pharmacol Toxicol. 1999;39:295-312.

\section{Submit your next manuscript to BioMed Central and take full advantage of:}

- Convenient online submission

- Thorough peer review

- No space constraints or color figure charges

- Immediate publication on acceptance

- Inclusion in PubMed, CAS, Scopus and Google Scholar

- Research which is freely available for redistribution

Submit your manuscript at

www.biomedcentral.com/submit

C Biomed Central 